\title{
Synthesis and Crystal Structure of $C_{1}$-Symmetric $3,3^{\prime}$-Bi(1,1'-dinaphthyl-camphopyrazole)
}

\author{
Jannis Barrera, ${ }^{1}$ Victoria A. Smolenski, ${ }^{2}$ Jerry P. Jasinski, ${ }^{2}$ and Jesús Pastrán ${ }^{1}$ \\ ${ }^{1}$ Departamento de Química, Universidad Simón Bolívar, Apartado 89000, Caracas 1020, Venezuela \\ ${ }^{2}$ Department of Chemistry, Keene State College, 229 Main Street, Keene, NH 03435-2001, USA \\ Correspondence should be addressed to Jesús Pastrán; jpastran@usb.ve
}

Received 29 March 2016; Accepted 8 May 2016

Academic Editor: Tej P. Singh

Copyright (C) 2016 Jannis Barrera et al. This is an open access article distributed under the Creative Commons Attribution License, which permits unrestricted use, distribution, and reproduction in any medium, provided the original work is properly cited.

\begin{abstract}
The compound 3,3'-bi(1,1'-dinaphthyl-camphopyrazole) $1, \mathrm{C}_{42} \mathrm{H}_{42} \mathrm{O}_{4}$, was obtained in good yield and structurally characterized by ${ }^{1} \mathrm{H}$ and ${ }^{13} \mathrm{C}$ NMR spectroscopy, elemental analysis, and X-ray diffraction. It consists of a 3,3'-bipyrazole group with each pyrazole ring containing a fused camphor group and a naphthalene ring bonded to the adjacent nitrogen atom in the ring. Both of the trimethyl, 5-membered rings of the fused camphor group form an envelope with the apex carbon atom as the flap in each case. In the crystal, weak $\pi-\pi$ stacking interactions are observed between nearby 6-carbon rings of the two naphthalene rings linking the molecules into extended chains. Weak $\pi$-ring intermolecular interactions are also observed between naphthalene atoms and pyrazole rings from each of the groups helping to stabilize the crystal packing. No classical hydrogen interactions are formed.
\end{abstract}

\section{Introduction}

During the last decade, a series of pyrazole-based ligands have been used for catalytic applications [1-3]. However, chiral pyrazole ligands derived from camphor coordinated to transition metals and the catalytic applications of the latter have been less explored [4]. Recently, chiral 3,3'-bipyrazole compounds have been proposed as important ligands that exert electronic and steric stronger influence to the metal center $[5,6]$. These ligands were prepared by condensation reaction between a bis-1.3-diketone previously reported [7, 8] and hydrazine hydrate, followed by aryl- or alkylation. Herein, we report the crystal structure of a $C_{1}$-symmetric $3,3^{\prime}$-bi (1,1'-dinaphthyl-camphopyrazole) $\mathbf{1}$ obtained by direct condensation with $\alpha$-naphthylhydrazine, which could have an even greater steric effect than the similar ligands previously reported in the literature.

\section{Materials and Methods}

2.1. General Remarks. ${ }^{1} \mathrm{H}$ and ${ }^{13} \mathrm{C}$ NMR spectra were recorded on a Jeol $400 \mathrm{MHz}$ spectrometer at $25^{\circ} \mathrm{C}$ with solvent signals allotted as internal standards. Melting point was determined on an Electrothermal Mel-Temp apparatus in open capillary tubes and is not corrected. CHN elemental analyses were performed on a Fisons EA 1108 analyzer and samples were air handled. Optical rotations were measured on a Perkin-Elmer 341 polarimeter.

2.2. Preparation of $3,3^{\prime}-B i\left(1,1^{\prime}\right.$-dinaphthyl-camphopyrazole $)$ [Systematic Name: (1,1'-Dinaphthyl-7, $7^{\prime}, 8,8,8^{\prime}, 8^{\prime}$-hexamethyl$4,4^{\prime}, 5,5^{\prime}, 6,6^{\prime}, 7,7^{\prime}$-octahydro-3,3'-bi-4,7-methano-indazole $\left.)\right] \mathbf{1}$. (1R, $\left.1^{\prime} \mathrm{R}\right)-3,3^{\prime}$-(1,2-Dihydroxyethane-1,2-di-ylidene)bis[1,7,7trimethylbicyclo[2,2,1]-heptan-2-one] (prepared using a modified procedure reported [7]) $(0.69 \mathrm{~g}, 1.95 \mathrm{mmoL})$ and $\alpha$-naphthylhydrazine hydrochloride (prepared using a modification of the reported procedure [9]) (1.14 g, $5.84 \mathrm{mmoL})$ were suspended in ethanol $(50.0 \mathrm{~mL})$. The resulting mixture was heated to reflux for 24 hours. Then, this mixture was neutralized with a saturated solution of $\mathrm{Na}_{2} \mathrm{CO}_{3}$. The solid obtained was filtered and washed with chloroform $(2 \times 15.0 \mathrm{~mL})$. The solvent was removed under vacuum to obtain the desired product $\mathbf{1}$ as a white solid $(0.58 \mathrm{~g}, 49 \%) . \mathrm{Mp}:(326 \pm 2)^{\circ} \mathrm{C}$. Elemental analysis is calculated for $\mathrm{C}_{42} \mathrm{H}_{42} \mathrm{~N}_{4} \cdot 0.4 \mathrm{H}_{2} \mathrm{O}$ : C $82.69 \%, \mathrm{H} 7.07 \%, \mathrm{~N}$ 9.18\%. Found: C $82.80 \%$, H 7.26\%, N 9.00\%. $[\alpha]_{\mathrm{e}}{ }^{20}=+139.3^{\circ}$ 


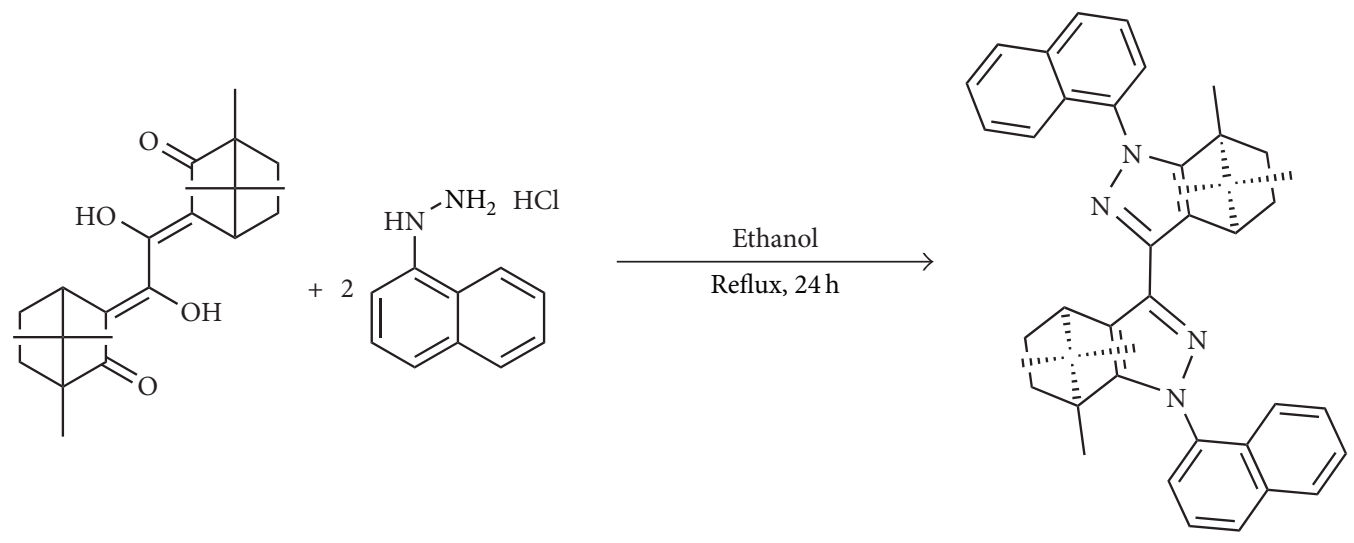

1

Scheme 1: Synthesis of 3,3'-bi(1,1'-dinaphthyl-camphopyrazole) 1.

(c $\left.1.008, \mathrm{CHCl}_{3}\right)$. IR $(\mathrm{KBr})\left(\nu, \mathrm{cm}^{-1}\right): 3055(\mathrm{w}), 2954(\mathrm{~m})$, 2870 (w), 1598 (m), 1422 (m), 1388 (m), 1041 (m), 804 (s), $774(\mathrm{~s}), 667.69(\mathrm{w}) .{ }^{1} \mathrm{H} \mathrm{NMR}\left(\mathrm{CDCl}_{3}\right): \delta=0.71(\mathrm{~s}, 3 \mathrm{H}$, $\left.\mathrm{CH}_{3}\right), 0.89\left(\mathrm{~s}, 3 \mathrm{H}, \mathrm{CH}_{3}\right), 0.97\left(\mathrm{~s}, 3 \mathrm{H}, \mathrm{CH}_{3}\right), 1.39-1.44$ (m, $\left.2 \mathrm{H}, \mathrm{CH}_{2}\right), 1.77-1.79(\mathrm{~m}, 1 \mathrm{H}, \mathrm{CH}), 2.14-2.19(\mathrm{~m}, 1 \mathrm{H}, \mathrm{CH})$, $3.15-3.16(\mathrm{~d}, J=4 \mathrm{~Hz}, 1 \mathrm{H}, \mathrm{CH}), 7.47-7.53(\mathrm{~m}, 4 \mathrm{H}$, aromatics $\mathrm{CH}), 7.76-7.78(\mathrm{~d}, J=8 \mathrm{~Hz}, 1 \mathrm{H}$, aromatics $\mathrm{CH}), 7.86-7.90(\mathrm{t}$, $2 \mathrm{H}$, aromatics $\mathrm{CH}) .{ }^{13} \mathrm{C}\left\{{ }^{1} \mathrm{H}\right\} \mathrm{NMR}\left(\mathrm{CDCl}_{3}\right): \delta=10.81,19.69$, 20.67, 27.64, 34.04, 48.53, 53.07, 62.90, 124.13, 124.79, 124.96, $126.48,126.84,127.28,127.80,128.98,131.09,134.08,136.97$, $139.94,156.89$. Crystals suitable for X-ray diffraction analysis were obtained by slow evaporation of a THF solution of the compound $(50.0 \mathrm{mg}$ in $5.0 \mathrm{~mL})$ at room temperature.

2.3. X-Ray Structure Determination of 3,3' - Bi(1,1' -dinaphthylcamphopyrazole) 1. X-ray diffraction data were collected using an Agilent, Eos, Gemini diffractometer with enhanced $\mathrm{X}$-ray source (Mo-K $\alpha$ radiation, $\lambda=0.71073 \AA$ ). Data collection, cell refinement, data reduction, structure solving, and refining were performed by using the following programs: CrysAlis PRO [10]; CrysAlis PRO [10]; CrysAlis RED [10]; ShelXT [11]; SHELXL [12]. Molecular graphics: Olex2 [13] was used to prepare the material for publication. Crystal data and experimental details are listed in Table 1. All $\mathrm{H}$ atoms were located in difference maps. The $\mathrm{C}-\mathrm{H}$ atoms were treated as riding atoms in geometrically idealized positions with $\mathrm{C}-\mathrm{H}$ distances of $0.95 \AA(\mathrm{CH})$ and $0.99 \AA\left(\mathrm{CH}_{2}\right)$ and refined with $U_{\text {iso }}(\mathrm{H})=1.2 U_{\text {eq }}(\mathrm{C})$. The $\mathrm{CH}_{3}$ atoms were treated as riding atoms in geometrically idealized positions with the $\mathrm{CH}_{3}$ distances of $0.98 \AA$ and refined with $U_{\text {iso }}(\mathrm{H})=1.5 U_{\text {eq }}(\mathrm{C})$. The Platon SQUEEZE program [14] was used to get rid of the solvent peaks. Absolute configurations were determined using 2351 quotients $[(I+)-(I-)] /[(I+)+(I-)][15]$. Supplementary crystallographic data for $\mathbf{1}$ are contained in CCDC 1458095. Copies of this information may be obtained free of charge from the Director, CCDC, 12 Union Road, Cambridge, CB2 1EZ, UK (fax: 144-1223-336033; e-mail: deposit@ccdc.cam.ac.uk or http://www.ccdc.cam.ac.uk/), or from the authors.
TABLE 1: Crystal data and experimental crystallographic details.

\begin{tabular}{|c|c|}
\hline & Compound 1 \\
\hline Empirical formula & $\mathrm{C}_{42} \mathrm{H}_{42} \mathrm{~N}_{4}$ \\
\hline Formula weight & 602.79 \\
\hline Temperature & $173 \mathrm{~K}$ \\
\hline Crystal system, space group & Monoclinic, $P 2_{1}$ \\
\hline \multirow{4}{*}{ Unit cell dimensions } & $a=7.4986(4) \AA$ \\
\hline & $b=25.7037(16) \AA$ \\
\hline & $c=10.7306(5) \AA$ \\
\hline & $\beta=104.001(5)^{\circ}$ \\
\hline Volume & $2006.78(19) \AA^{3}$ \\
\hline$Z$, calculated density & $2,0.998 \mathrm{Mg} \mathrm{m}^{-3}$ \\
\hline Absorption coefficient & $0.06 \mathrm{~mm}^{-1}$ \\
\hline$F(000)$ & 644 \\
\hline Crystal size & $0.42 \times 0.28 \times 0.22(\mathrm{~mm})$ \\
\hline$\theta$ range for data collection & 3.8 to $32.0^{\circ}$ \\
\hline Index ranges & $\begin{array}{c}-10 \leq h \leq 10,-32 \leq k \leq 38 \\
-15 \leq l \leq 16\end{array}$ \\
\hline Reflections collected & 15094 \\
\hline Independent reflections & $10751\left[R_{\text {(int) }}=0.041\right]$ \\
\hline Data/restraints/parameters & $10751 / 1 / 421$ \\
\hline Goodness-of-fit on $F^{2}$ & 1.03 \\
\hline Final $R$ indices $[I>2(I)]^{\mathrm{a}}$ & $R_{1}=0.077, w R_{2}=0.1823$ \\
\hline$R$ indices (all data) & $R_{1}=0.1011, w R_{2}=0.2005$ \\
\hline Largest diff. peak and hole & 0.30 and $-0.37 \mathrm{e} \AA^{-3}$ \\
\hline Absolute structure parameter & $-1.6(10)$ \\
\hline
\end{tabular}

\section{Results and Discussion}

$3,3^{\prime}-\mathrm{Bi}\left(1,1^{\prime}\right.$-dinaphthyl-camphopyrazole) 1 was prepared by condensation reaction between bis-1.3-diketone and $\alpha$ naphthylhydrazine hydrochloride (Scheme 1). The identity 


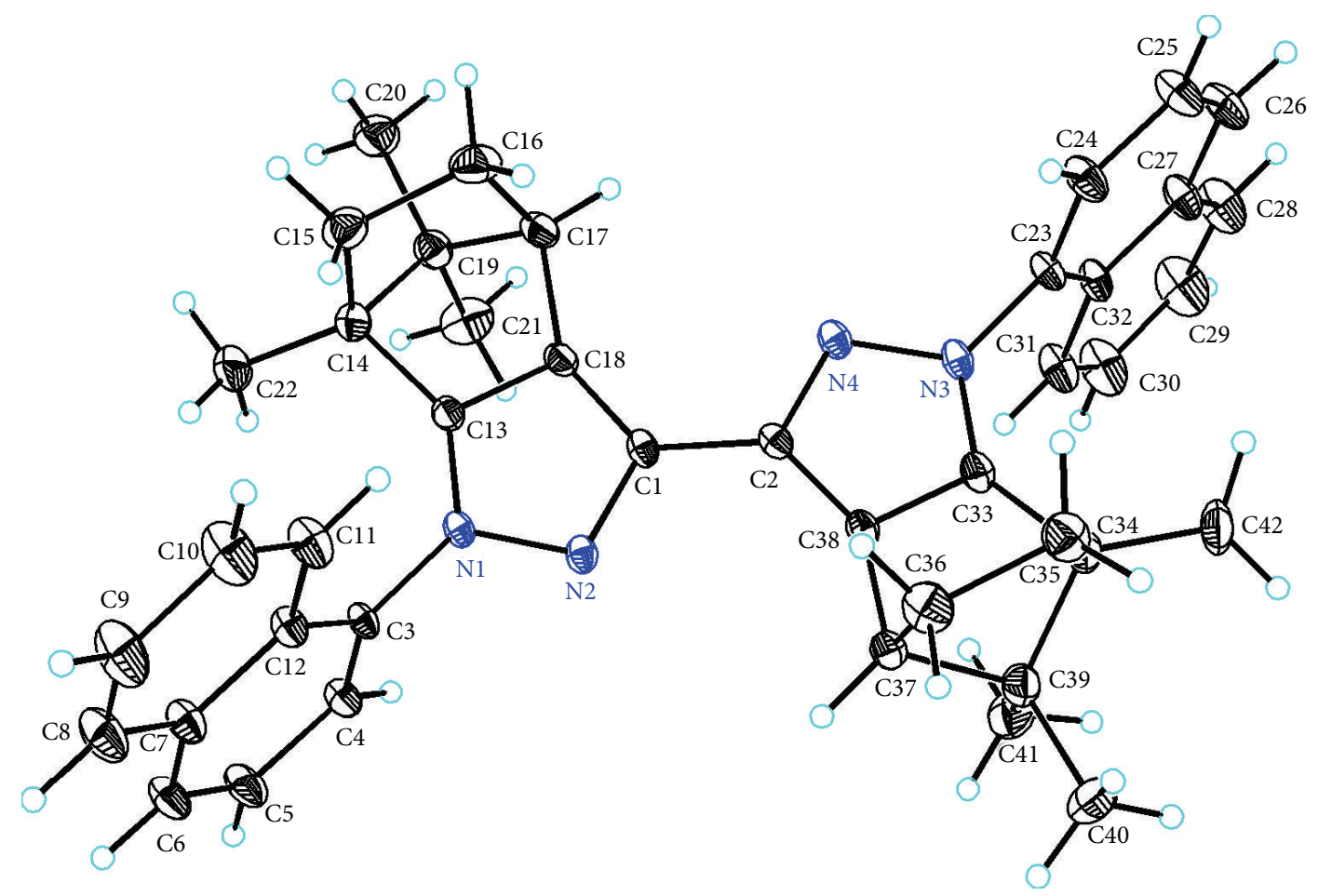

FIgURE 1: View of 3,3'-bi(1,1'-dinaphthyl-camphopyrazole) 1 showing the atom-labelling. Displacement ellipsoids are drawn at the $50 \%$ probability level. Selected bond lengths $(\AA)$ and angles $\left({ }^{\circ}\right)$ are N1-N2 1.377(4), N2-C1 1.354(4), C1-C2 1.446(4), C2-N4 1.346(4), N4-N3 1.365(4), N1-N2-C1 104.9(2), N2-C1-C2 119.7(3), C1-C2-N4 119.6(3), and C2-N4-N3 105.6(3).

of the compound was established by ${ }^{1} \mathrm{H}$ and ${ }^{13} \mathrm{C}$ NMR spectroscopy and elemental analysis. Crystals suitable for an X-ray crystal structure determination grew from slow evaporation of a tetrahydrofuran solution of the compound at room temperature. It consists of a $3,3^{\prime}$-bipyrazole group with $E$ configuration. Each pyrazole ring contains a fused camphor group and a naphthalene ring bonded to the adjacent nitrogen atom in the ring (Figure 1). The bond lengths and angles values found for the fused camphor group correspond with characteristic values reported in similar compounds [16].

1 crystallizes in the space group $P 2_{1}$ with two independent molecules in the unit cell. The dihedral angle between the mean planes of the two pyrazole rings is $3.9(1)^{\circ}$. The mean planes of the naphthalene rings are tilted by $88.8(1)^{\circ}$ and $88.8(2)^{\circ}$ with regard to that of the pyrazole ring and $2.1(3)^{\circ}$ with each other. The mean plane of the 5-membered ring of the camphor group is twisted by $44.2(3)^{\circ}$ and $44.2(1)^{\circ}$, respectively, with that of the pyrazole ring forming an indazole-like altered motif. Both of the trimethyl, 5-membered rings of the fused camphor group form an envelope with the apex carbon (C19, $\varphi=252.5(4)$ and C39, $\varphi=252.9(4))$ forming the flap atom in each case. In the crystal, weak $\pi-\pi$ stacking interactions are observed between nearby 6 -carbon rings (Cg1 and $\mathrm{Cg} 2)$ of the two naphthalene rings $(\mathrm{Cg} 1-\mathrm{Cg} 2=3.644 \AA$; $1+x,+y, 1+z$; where $\mathrm{Cg} 1=\mathrm{C} 11 / \mathrm{C} 12 / \mathrm{C} 7 / \mathrm{C} 8 / \mathrm{C} 9 / \mathrm{C} 10$ and $\mathrm{Cg} 2$ $=\mathrm{C} 31 / \mathrm{C} 32 / \mathrm{C} 27 / \mathrm{C} 28 / \mathrm{C} 29 / \mathrm{C} 30)$ linking the molecules into extended chains (Figure 2).
TABLE 2: Distances and angles $\left(\AA,^{\circ}\right)$ of hydrogen bonding interactions. The $\mathrm{H}$ atoms are in calculated positions (D: donor; $\mathrm{A}$ : acceptor; H: hydrogen).

\begin{tabular}{lccc}
\hline $\mathrm{D}-\mathrm{H} \cdots \mathrm{A}$ & $\mathrm{H} \cdots \mathrm{A}$ & $\mathrm{D} \cdots \mathrm{A}$ & $\mathrm{D}-\mathrm{H} \cdots \mathrm{A}$ \\
\hline $\mathrm{C} 4-\mathrm{H} 4 \cdots \mathrm{Cg} 4$ & 2.91 & $3.698(4)$ & 141 \\
$\mathrm{C} 24-\mathrm{H} 24 \cdots \mathrm{Cg} 3$ & 2.93 & $3.747(4)$ & 144
\end{tabular}

$\mathrm{Cg} 3=\mathrm{N} 1 / \mathrm{N} 2 / \mathrm{Cl} / \mathrm{C} 13 / \mathrm{C} 18 ; \mathrm{Cg} 4=\mathrm{N} 3 / \mathrm{N} 4 / \mathrm{C} 2 / \mathrm{C} 33 / \mathrm{C} 38 ;$ symmetry codes: (i) $x+1, y, z$; (ii) $x-1, y, z$.

Weak $\pi$-ring intermolecular interactions are also seen between naphthalene atoms and pyrazole rings from each of the groups helping to stabilize the crystal packing. No classical hydrogen interactions $(\mathrm{C}-\mathrm{H} \cdots \pi)$ are formed (Table 2$)$.

\section{Summary}

The compound $3,3^{\prime}$-bi(1,1'-dinaphthyl-camphopyrazole) 1 has been prepared and characterized by NMR spectroscopy, elemental analysis, and single crystal X-ray diffraction. The solid-state structure shows the spatial arrangement of the naphthyl groups with respect to the pyrazole ring and intermolecular interactions that sustain the crystal.

\section{Competing Interests}

The authors declare that they have no competing interests. 


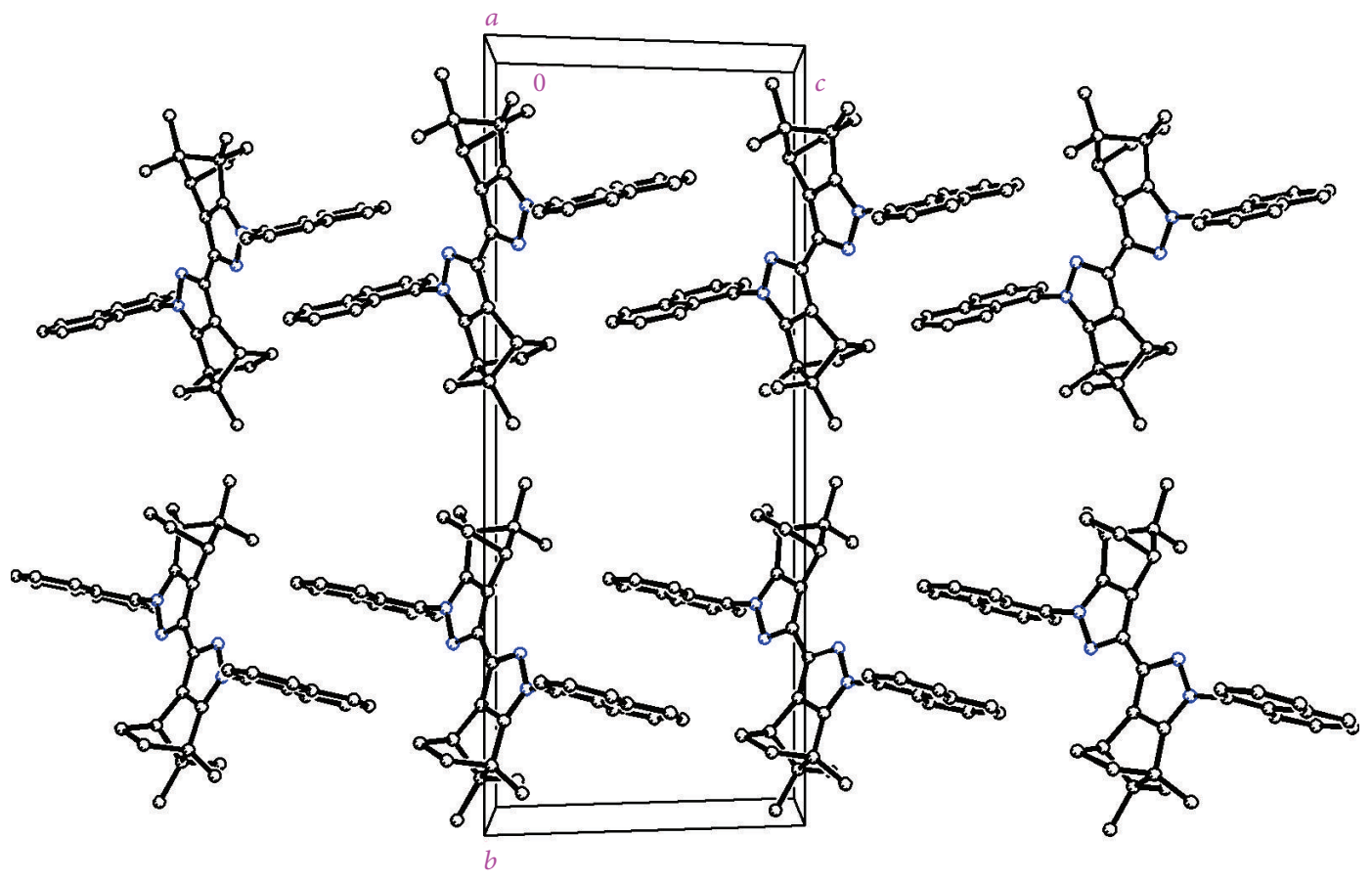

Figure 2: Molecular packing of 3,3'-bi(1,1'-dinaphthyl-camphopyrazole) 1 viewed along the $a$ axis.

\section{Acknowledgments}

This work was financed by DID-USB (Project S1-IN-CB005-12). The authors thank T.S.U Eleinne Severino (Centro de Química, Instituto Venezolano de Investigaciones Científicas) for carrying out the elemental analyses. Jerry P. Jasinski acknowledges the NSF-MRI program (Grant no. CHE1039027) for funds to purchase the X-ray diffractometer.

\section{References}

[1] A. Togni, U. Burckhardt, V. Gramlich, P. S. Pregosin, and R. Salzmann, "Palladium-catalyzed asymmetric allylic amination using ferrocenyl pyrazole ligands: steric control of $\eta^{3}$-allyl configuration and site-selective nucleophilic attack," Journal of the American Chemical Society, vol. 118, no. 5, pp. 1031-1037, 1996.

[2] H. Willms, W. Frank, and C. Ganter, "Coordination chemistry and catalytic application of bidentate phosphaferrocenepyrazole and -imidazole based P,N-ligands," Organometallics, vol. 28, no. 10, pp. 3049-3058, 2009.

[3] Y. Kashiwame, S. Kuwata, and T. Ikariya, "Metal-pyrazole bifunction in half-sandwich $\mathrm{C}-\mathrm{N}$ chelate iridium complexes: pyrazole-pyrazolato interconversion and application to catalytic intramolecular hydroamination of aminoalkene," ChemistryA European Journal, vol. 16, no. 3, pp. 766-770, 2010.

[4] T. Godau, S. M. Bleifuß, A. L. Müller et al., " $\mathrm{Cu}(\mathrm{I})$ catalysed cyclopropanation with enantiopure scorpionate type ligands derived from (+)-camphor or (-)-menthone," Dalton Transactions, vol. 40, no. 24, pp. 6547-6554, 2011.

[5] M. J. Spallek, S. Stockinger, R. Goddard, F. Rominger, and O. Trapp, "Bulky and modular 3,3'-bipyrazoles as ligands: synthesis, characterization, and catalytic activity of Pd complexes,"
European Journal of Inorganic Chemistry, no. 32, pp. 5014-5024, 2011.

[6] M. J. Spallek, S. Stockinger, R. Goddard, and O. Trapp, "Modular palladium bipyrazoles for the isomerization of allylbenzenesmechanistic considerations and insights into catalyst design and activity, role of solvent, and additive effects," Advanced Synthesis and Catalysis, vol. 354, no. 8, pp. 1466-1480, 2012.

[7] I. J. Hart, "Preparation of dimetal complexes exhibiting $C_{2}$ symmetry using a chiral bis-1,3-diketonate ligand," Polyhedron, vol. 11, no. 7, pp. 729-734, 1992.

[8] C. R. Noe, M. Knollmüller, P. Gärtner, K. Mereiter, and G. Steinbauer, "Chiral Lactols, XIV. Stereoselective fusion of fivemembered ring lactols to the bornane ring system," Liebigs Annalen, vol. 1996, no. 6, pp. 1015-1021, 1996.

[9] P. S. Portoghese, M. Sultana, and A. E. Takemori, "Design of peptidomimetic $\delta$ opioid receptor antagonists using the message-address concept," Journal of Medicinal Chemistry, vol. 33, no. 6, pp. 1714-1720, 1990.

[10] Agilent, CrysAlis PRO \& CrysAlis RED, Agilent Technologies, Yarnton, UK, 2014.

[11] G. M. Sheldrick, "Crystal structure refinement with SHELXL," Acta Crystallographica Section C, vol. 71, pp. 3-8, 2015.

[12] G. M. Sheldrick, "A short history of SHELX," Acta Crystallographica Section A, vol. 64, pp. 112-122, 2008.

[13] O. V. Dolomanov, L. J. Bourhis, R. J. Gildea, J. A. K. Howard, and H. Puschmann, "OLEX2: a complete structure solution, refinement and analysis program," Journal of Applied Crystallography, vol. 42, no. 2, pp. 339-341, 2009.

[14] A. L. Spek, "PLATON SQUEEZE: a tool for the calculation of the disordered solvent contribution to the calculated structure factors," Acta Crystallographica Section C, vol. 71, pp. 9-18, 2015.

[15] S. Parsons, H. D. Flack, and T. Wagner, "Use of intensity quotients and differences in absolute structure refinement," 
Acta Crystallographica Section B: Structural Science, Crystal Engineering and Materials, vol. 69, no. 3, pp. 249-259, 2013.

[16] A. Llamas-Saiz, C. Foces-Foces, I. Sobrados, J. Elguero, and W. Meutermans, "(4S,7R)-7,8,8-Trimethyl-4,5,6,7-tetrahydro4,7-methano- $1 \mathrm{H}(2 \mathrm{H})$-indazole (campho[2,3-c]pyrazole): comparison between the X-ray structure and carbon-13 NMR data in the solid state," Acta Crystallographica Section C: Crystal Structure Communications, vol. 49, pp. 724-729, 1993. 

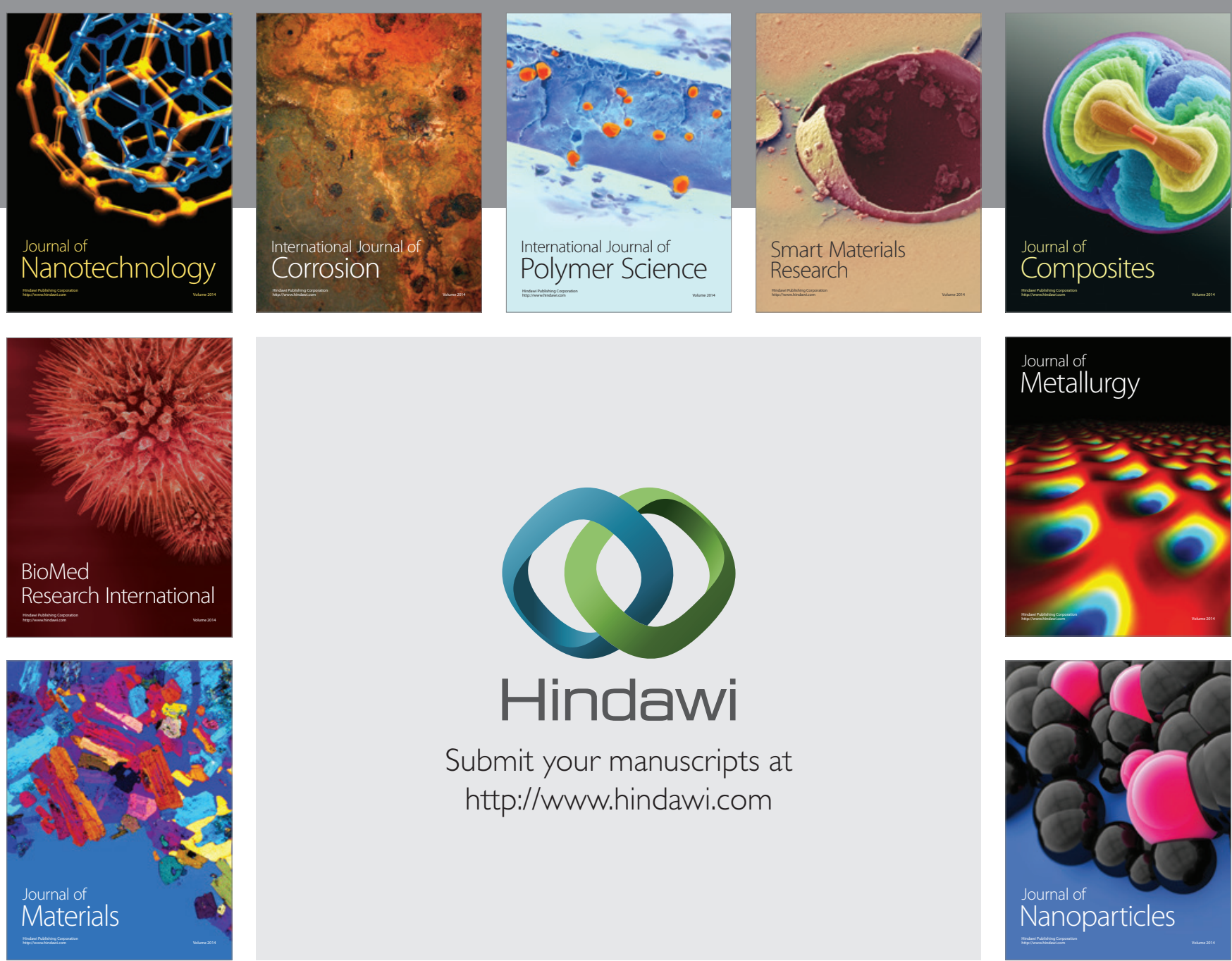

\section{Hindawi}

Submit your manuscripts at

http://www.hindawi.com

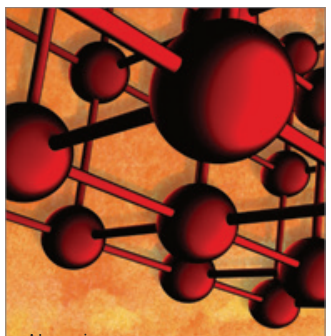

Materials Science and Engineering
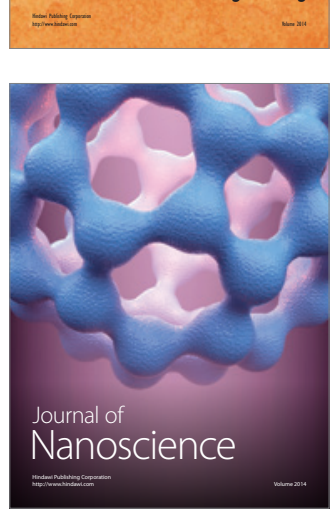
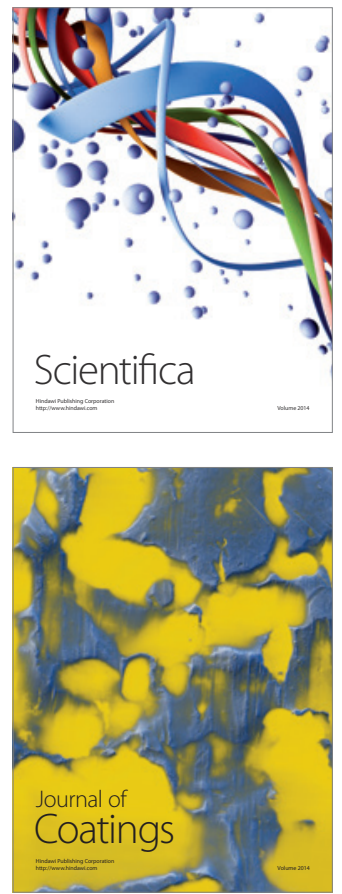
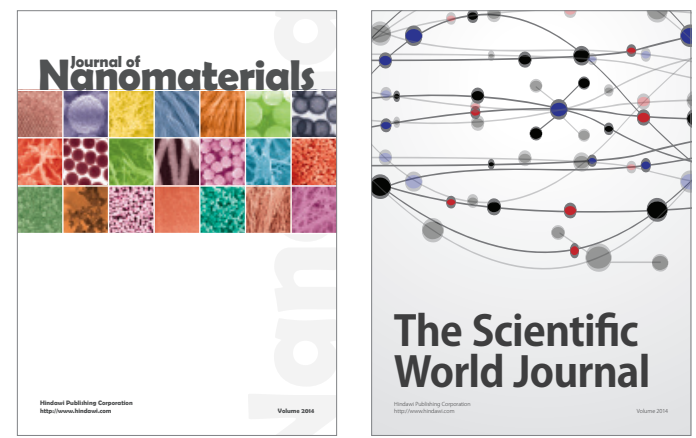

The Scientific World Journal
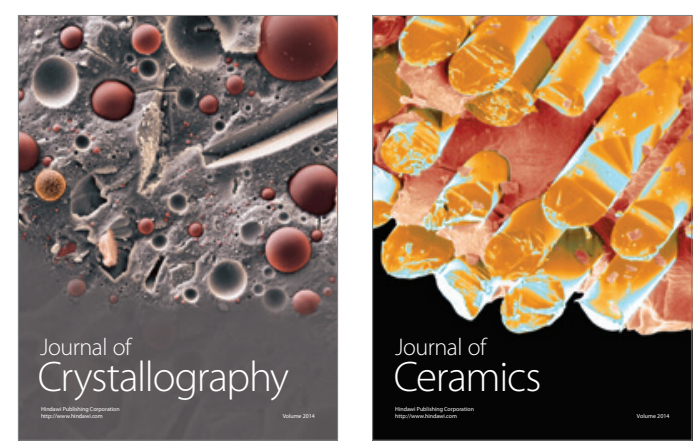
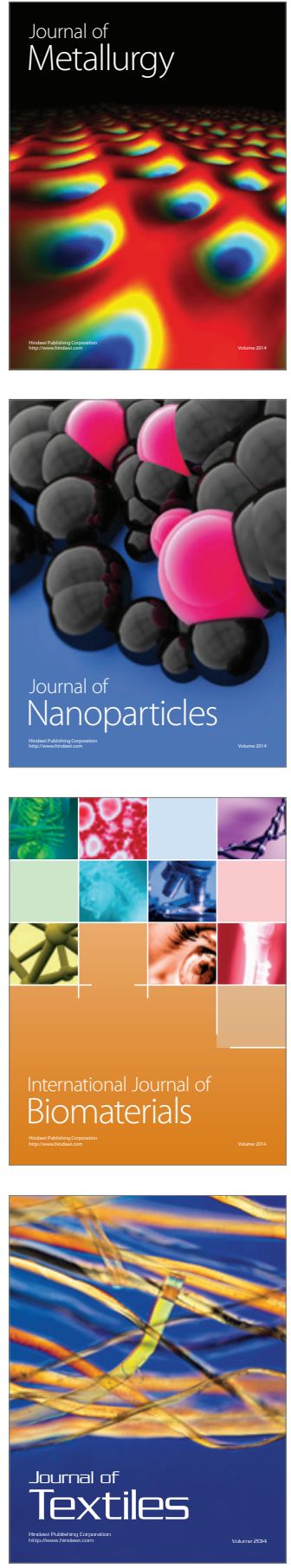